\title{
ANALISIS HUBUNGAN KUALITAS AIR MINUM DAN KEJADIAN DIARE DI WAWONDULA SEBAGAI WILAYAH PEMBERDAYAAN PT. VALE SOROWAKO
}

\author{
Andi Zulkifli', Kristiawan Basuki Rahmat ${ }^{2}$, dan Andi Ruhban ${ }^{3}$ \\ 1'2' PT. Vale Sorowako \\ 3Jurusan Kesehatan Lingkungan Politeknik kesehatan Makassar
}

\begin{abstract}
Diarrhea is still a major health problem, especially in developing countries, including Indonesia. The purpose of this study was to analyze the relationship between drinking water quality and diarrhea occurrence in the empowerment area of PT.Vale Indonesia. This study used cross sectional design which is one of the analytic epidemiological research designs, and included in observational research type with diarrhea respondents from January to July 2016 . The results showed the relationship between the distance of pollutant sources with bacteriological quality, the construction of clean water facilities with bacteriological quality and the quality of drinking water with the occurrence of diarrhea. Significantly related variables were bacteriological quality (0.02), treatment action $(0,000)$ and hygiene behavior $(0.000)$. The most influential variable on the occurrence of diarrhea is the processing action. Based on the result of research, it is concluded that, the distance of dug well with pollutant source, dug well construction and processing action affect drinking water quality and diarrhea occurrence.
\end{abstract}

Keywords: Diarrhea, Bacteriological Quality, Hygiene Behavior

\section{A. PENDAHULUAN}

Air merupakan kebutuhan mutlak bagi kehidupan manusia, baik dari segi kualitas maupun dari segi kuantitasnya. Tubuh manusia sebagian besar terdiri dari air dan air ini didapatkan dari makanan dan minuman. Kandungan air dalam tubuh manusia berkisar antara 60 - $80 \%$ dari berat badan. Air disamping vital bagi kehidupan manusia juga mempunyai peranan dalam menimbulkan atau menularkan penyakit water borne disease baik yang termasuk penyakit infeksi seperti penyakit diare (Daud, 2001).

Orang akan dehidrasi atau terserang penyakit bila kekurangan cairan dalam tubuhnya. Persoalannya, saat ini kualitas air minum di kota-kota besar di Indonesia masih memprihatinkan. Kepadatan penduduk, tata ruang yang salah dan tingginya eksploitasi sumber daya air sangat berpengaruh pada kualitas air. Pemerintah telah mengeluarkan Permenkes No 492/Menkes/PER/IV/2010 tentang Persyaratan Kualiatas Kualitas Air Minum. "Syarat air minum sesuai Permenkes itu harus bebas dari bahan-bahan anorganik dan organik. Dengan kata lain kualitas air minum harus bebas bakteri, zat kimia, racun, limbah berbahaya dan lain sebagainya. Parameter kualitas air minum yang berhubungan langsung dengan kesehatan sesuai Permenkes tersebut adalah berhubungan dengan mikrobiologi, seperti bakteri E.coli dan total coliform.
Air minum yang ideal seharusnya jernih, tidak berwarna, tidak berasa, tidak berbau. Air minum juga seharusnya tidak mengandung kuman patogen dan segala makhluk yang membahayakan kesehatan manusia. Tidak mengandung zat kimia yang dapat mengubah fungsi tubuh, tidak korosif dan tidak meninggalkan endapan pada seluruh jaringan distribusi (Soemirat, 2004). Oleh karena itu sebagai bagian dari keamanan dalam bidang kesehatan terhadap konsumsi air dari sumber air diperlukan analisis kualitas air untuk mengetahui tingkat kelayakan konsumsi dan analisis kebutuhan konsumsi air penduduk dengan debit maksimum yang dapat dikomsumsi (Herlambang, 2007).

\section{B. BAHAN DAN METODE}

\section{Lokasi Penelitian:}

Lokasi penelitian adalah Desa Wawondula Kecamatan Towuti Kabupaten Luwu Timur. Lokasi ini merupakan wilayah pemberdayaan PT. Vale Sorowako

Jumlah Kepala Keluarga sebanyak 978 KK. Penentuan lokasi tersebut didasarkan atas pertimbangan sebagai berikut: 1) Semua lokasi tersebut telah memiliki sumber air 2) Penderita diare yang dilaporkan cukup tinggi 3) semua telah memiliki sumber air bersih dan tercatat dengan baik di Administrasi dengan alamat yang jelas sehingga mudah ditemukan.

\section{Desain dan Variabel Penelitian}

Penelitian ini menggunakan desain cross sectional yang merupakan salah satu jenis 
rancangan penelitian epidemiologis yang sifatnya analitik, dan termasuk dalam jenis penelitian observasional. Secara epidemiologis desain ini bertujuan untuk menjawab pertanyaan tentang hubungan antara penyakit dengan paparannya, dengan cara mengamati status paparan dan penyakit pada individu-individu dari suatu populasi. Dalam penerapannya pada penelitian Kualitas Air dengan kejadian Diare maka desain ini dimaksudkan untuk mempelajari hubungan antara beberapa variabel independen yang berlaku sebagai variabel prediktor variabel dependennya yakni Kejadian Diare di Wawondula Sulawesi Selatan. Penelitian ini dilakukan dengan menempuh langkah-langkah seperti: 1) penetapan unit analisis penelitian, 2) identifikasi variabel penelitian, 3) penetapan waktu dan lokasi penelitian, 4) pengukuran variabel, serta 5) analisis hasil penelitian

\section{Populasi dan Sampel}

Populasi adalah penderita yang berobat di Puskesmas Wawondula selama periode bulan Januari sampai dengan bulan Juli tahun 2016 sebanyak 2415 penderita. Sampel diambil secara non random, purposive sampling yakni penderita diare sebanyak 100 responden dan bukan penderita diare sebanyak 100 responden dengan tujuan untuk membandingkan kelompok penderita diare dengan bukan penderita diare serta mencari penyebabnya. Penarikan sample dengan menggunakan metode purposive sampling dengan alasan bahwa, sarana air bersih sebagai sumber air minum yang digunakan responden pada umumnya sama yaitu sumur gali. Penggunaan metode sampling bertujuan untuk menarik kesimpulan populasi yang didasarkan pada dan hasil pemeriksaan yang dipenuhi melalui penelitian populasi tersebut

\section{Pengumpulan data}

Untuk data penyakit Diare dikumpulkan dengan cara melakukan C. HASIL PENELITIAN wawancara langsung dengan responden dengan menggunakan kuisioner dan data sarana air bersih digunakan lembar observasi yang telah disusun sebelumnya berdasarkan tujuan penelitian yang akan dicapai, sedangkan kualitas air minum dengan melakukan analisis laboratorium

\section{Analisa data meliputi :}

\section{Analisis Univariate}

Analisis Univariate dilakukan dengan mendistribusikan data hasil pengukuran dalam bentuk tabel distribusi frekuensi. Data yang dianalisis adalah kualitas air minum pada wilayah penelitian. Selanjutnya untuk mencermati normalitas data dilakukan perhitungan prosentase dan kecenderungan pemusatan data.

\section{Analisis Bi-variate}

Analisis Bi-variate dilakukan untuk mengetahui adanya keterkaitan kualitas air minum dengan terjadinya kejadian diare. Teknik analisis data dilakukan dengan pengujian statistik, uji Chi Square dan Yate's correction $\left(X^{2}\right)$.

$$
\begin{aligned}
& \text { Rumus : } X^{2}=\Sigma \text {-- } \frac{(\mathrm{O}-\mathrm{E})^{2}}{\mathrm{-a}} \\
& \text { Keterangan : } \\
& \text { O : Nilai Observasi } \\
& \text { Expeated } \\
& \text { df : Degree of Freedom } \\
& \mathrm{E} \text { : } \quad \text { Nilai dengan }(\mathrm{b}-1) \\
& (k-1)
\end{aligned}
$$

\section{Analisis Multivariat}

Analisis Multivariat dilakukan untuk mengetahui faktor mana yang paling dominan terhadap terjadinya kasus diare. Pada analisis ini semua faktor yang berpengaruh dianalisis secara bersamaan sehingga nampak faktor yang paling besar pengaruhnya dibandingkan dengan faktor lain.

\section{Analisis Hubungan Jarak dengan Kualitas Bakteriologis di Wawondula Tahun 2016}

Tabel 1 Hubungan Jarak Sumber Pencemaran Dengan Kualitas Bakteriologis Air Minum di Wawondula Tahun 2016

\begin{tabular}{ccccccccc}
\hline \multirow{2}{*}{$\begin{array}{c}\text { Jarak Sumber } \\
\text { Pencemaran }\end{array}$} & \multicolumn{4}{c}{ Kualitas Bakteriologis } & & \multicolumn{2}{c}{ Total } \\
\cline { 2 - 5 } & \multicolumn{2}{c}{ Tidak } & \multicolumn{2}{c}{ Ya } & $\%$ \\
\hline \multirow{2}{*}{ Tidak Memenuhi syarat } & 115 & 94.5 & 20 & 40.5 & & 135 & 100.0
\end{tabular}




\begin{tabular}{lrrrrrr}
\hline Memenuhi Syarat & 25 & 38.5 & 40 & 61.5 & 65 & 100.0 \\
\hline Total & 140 & 70.0 & 60 & 30.0 & 200 & 100.0 \\
\hline
\end{tabular}

Sumber : Data Primer 2016

Tabel 1. menunjukan bahwa responden yang jarak dengan sumber pencemaran memenuhi syarat dengan kualitas bakteriologis tidak memenuhi syarat sebanyak 25 responden $(38.5 \%)$, dan responden yang jarak dengan sumber pencemaran yang tidak memenuhi syarat dengan kualitas bakteriologis tidak memenuhi syarat sebanyak 115 responden (94.5\%). Hal ini menunjukan bahwa persentase kualitas bakteriologis pada jarak dengan sumber pencemaran yang tidak memenuhi syarat lebih tinggi dibanding pada responden dengan jarak sumber pencemar yang memenuhi syarat . Secara statistik terdapat hubungan yang signifikan dengan nilai $p=0.000(p<0,05)$, artinya terdapat hubungan yang bermakna antara jarak sumber pencemar dengan kualitas bakteriologis

\section{Analisis Hubungan Konstruksi dengan Kualitas Bakteriologis Air Minum di Wawondula Tahun 2016}

Hasil analisis mengenai konstruksi sarana air minum dengan kualitas bakteriologis dapat dilihat dalam tabel berikut:

Tabel 2 Hubungan Konstruksi Dengan Kualitas Bakteriologis Air Minum di Wawondula Tahun 2016

\begin{tabular}{|c|c|c|c|c|c|c|}
\hline \multirow{3}{*}{ Konstruksi } & \multicolumn{4}{|c|}{ Kualitas Bakteriologis } & \multirow{2}{*}{\multicolumn{2}{|c|}{ Total }} \\
\hline & \multicolumn{2}{|c|}{ Tidak Memenuhi } & \multicolumn{2}{|c|}{ Memenuhi Syarat } & & \\
\hline & $\mathrm{n}$ & $\%$ & $\mathrm{n}$ & $\%$ & $\mathrm{n}$ & $\%$ \\
\hline $\begin{array}{l}\text { Tidak Memenuhi } \\
\text { syarat }\end{array}$ & 117 & 85.4 & 20 & 14.6 & 137 & 100.0 \\
\hline Memenuhi Syarat & 23 & 36.5 & 40 & 63.5 & 63 & 100.0 \\
\hline Total & 140 & 70.0 & 60 & 30.0 & 200 & 100.0 \\
\hline
\end{tabular}

Sumber: Data Primer 2016

Tabel 2 menunjukan bahwa responden yang memiliki sarana air minum dengan konstruksi memenuhi syarat dengan kualitas bakteriologis tidak memenuhi syarat sebanyak 23 responden (36.5\%), dan responden yang konstruksi tidak memenuhi syarat dengan kualitas bakteriologis tidak memenuhi syarat sebanyak 117 responden (85.4\%). Hal ini menunjukan bahwa persentase kualitas bakteriologis pada konstruksi yang tidak memenuhi syarat lebih tinggi dibanding pada responden dengan konstruksi yang memenuhi syarat. Secara statistik terdapat hubungan yang signifikan dengan nilai $p=0.000(p<0,05)$, artinya terdapat hubungan yang bermakna antara konstruksi sarana air minum dengan kualitas bakteriologis.

\section{Analisis Hubungan Kualitas Bakteriologis dengan Kejadian Diare di Wawondula Tahun 2006}

Hasil analisis kualitas baktriologis dengan kejadian diare, dapat dilihat dalam tabel berikut: 


\begin{tabular}{|c|c|c|c|c|c|c|}
\hline \multirow{3}{*}{ Kualitas Bakteriologis } & \multicolumn{4}{|c|}{ Kejadian Diare } & \multirow{2}{*}{\multicolumn{2}{|c|}{ Total }} \\
\hline & \multicolumn{2}{|c|}{ Ada } & \multicolumn{2}{|c|}{ Tidak } & & \\
\hline & $\mathrm{n}$ & $\%$ & $\mathrm{n}$ & $\%$ & $\mathrm{n}$ & $\%$ \\
\hline $\begin{array}{l}\text { Tidak Memenuhi } \\
\text { Syarat }\end{array}$ & 78 & 55.7 & 62 & 44.3 & 140 & 100 \\
\hline Memenuhi Syarat & 22 & 36.7 & 38 & 63.3 & 60 & 100 \\
\hline Total & 100 & 50.0 & 100 & 50.0 & 200 & 100 \\
\hline
\end{tabular}

Sumber : Data Primer 2016

Pada tabel 3 menunjukan bahwa responden dengan kualitas bakteriologis memenuhi syarat dan menderita diare sebanyak 22 responden (36.7\%), dan kualitas bakteriologis yang tidak memenuhi syarat dan menderita diare sebanyak 78 responden $(55.7 \%)$.

$\mathrm{Hal}$ ini menunjukan bahwa persentase penderita diare pada kualitas bakteriologis yang tidak memenuhi syarat lebih tinggi dibanding pada responden dengan kualitas bakteriologis memenuhi syarat. Secara statistik terdapat hubungan yang signifikan dengan nilai $\mathrm{p}=0.020 \quad(\mathrm{p}<0,05)$, artinya ada hubungan yang bermakna antara kualitas bakteriologis dengan kejadian diare di Wawondula.

\section{Analisis Hubungan Tindakan Pengolahan dengan Kejadian Diare di Wawondula Tahun} 2006

Hasil analisis tindakan pengolahan dengan kejadian diare dapat dilihat dalam tabel berikut

Tabel 4. Hubungan Tindakan Pengolahan Air Minum dengan kejadian Diare di Wawondula Tahun 2016

\begin{tabular}{|c|c|c|c|c|c|c|}
\hline \multirow{3}{*}{$\begin{array}{c}\text { Tindakan } \\
\text { Pengolahan }\end{array}$} & \multicolumn{4}{|c|}{ Kejadian Diare } & \multirow{2}{*}{\multicolumn{2}{|c|}{ Total }} \\
\hline & \multicolumn{2}{|c|}{ Ada } & \multicolumn{2}{|c|}{ Tidak } & & \\
\hline & $\mathrm{n}$ & $\%$ & $\mathrm{n}$ & $\%$ & $\mathrm{n}$ & $\%$ \\
\hline $\begin{array}{l}\text { Tidak Memenuhi } \\
\text { Syarat }\end{array}$ & 89 & 94.7 & 5 & 5.3 & 94 & 100 \\
\hline Memenuhi Syarat & 11 & 10.4 & 95 & 89.6 & 106 & 100 \\
\hline Total & 100 & 50.0 & 100 & 50.0 & 200 & 100 \\
\hline
\end{tabular}

Sumber : Data Primer 2016

Tabel 4 menunjukan bahwa responden yang tindakan pengolahan memenuhi syarat dan menderita diare sebanyak 11 responden (10.4\%), dan responden

5. Analisis Hubungan Perilaku Higiene dengan Kejadian Diare di Wawondula Tahun 2006 Tabel 5 Hubungan Perilaku Hygiene dengan Jejadian Diare di Wawondula Tahun 2016

\begin{tabular}{|c|c|c|c|c|c|c|}
\hline \multirow{3}{*}{ Prilaku Hygiene } & \multicolumn{4}{|c|}{ Kejadian Diare } & \multirow{2}{*}{\multicolumn{2}{|c|}{ Total }} \\
\hline & \multicolumn{2}{|c|}{ Ada } & \multicolumn{2}{|c|}{ Tidak } & & \\
\hline & $\mathrm{n}$ & $\%$ & $\mathrm{n}$ & $\%$ & $\mathrm{n}$ & $\%$ \\
\hline $\begin{array}{l}\text { Tidak Memenuhi } \\
\text { Syarat }\end{array}$ & 79 & 79.0 & 7 & 7.0 & 86 & 100.0 \\
\hline Memenuhi Syarat & 21 & 18.4 & 93 & 81.6 & 114 & 100.0 \\
\hline Total & 100 & 50.0 & 100 & 50.0 & 200 & 100.0 \\
\hline
\end{tabular}

Sumber : Data Primer 2016

Tabel 5 menunjukan bahwa responden dengan perilaku hygiene yang memenuhi syarat dan menderita diare sebanyak 21 responden dengan tindakan pengolahan yang tidak memenuhi syarat dan menderita diare sebanyak 89 responden (94.7\%). 
Hal ini menunjukan bahwa persentase penderita diare pada responden dengan perilaku hygiene yang tidak memenuhi syarat lebih tinggi dibanding pada responden dengan perilaku hygiene memenuhi syarat. Secara statistik terdapat hubungan yang signifikan dengan nilai $p=0.000 \quad(p<0,05)$, artinya terdapat hubungan yang bermakna antara perilaku hygiene dengan kejadian diare di Wawondula.

\section{PEMBAHASAN}

\section{Analisis Hubungan Kualitas Bakteriologis dengan Kejadian Diare}

Tabel 1. menunjukan bahwa responden dengan kualitas bakteriologis memenuhi syarat dan menderita diare sebanyak 22 responden $(36.7 \%)$, dan kualitas bakteriologis yang tidak memenuhi syarat dan menderita diare sebanyak 78 responden (55.7\%). Hal ini menunjukan bahwa persentase penderita diare pada kualitas bakteriologis yang tidak memenuhi syarat lebih tinggi dibanding pada responden dengan kualitas bakteriologis memenuhi syarat. Secara statistik terdapat hubungan yang signifikan dengan nilai $p=0.020$ $(p<0,05)$, artinya ada hubungan yang bermakna antara kualitas bakteriologis dengan kejadian diare di Wawondula.

Penelitian ini didukung oleh penelitian Rini Ernawati (2006) bahwa sanitasi sumber air bersih dalam hal ini adalah kualitas bakteriologis mempengaruhi kejadian diare di RSUP Abdul Wahab Syahrani Samarinda, dan penelitian Abidin Sam (2004) didapatkan bahwa kontribusi kualitas air terhadap kejadian diare dengan uji koefisien kontingensi adalah 0.223 atau $22.0 \%$.

Kualitas bakteriologis air sangat dipengaruhi oleh jarak sumber air dengan sumber pencemaran, karena kemampuan bakteri bergerak dalam sehari untuk mencapai sumber air menentukan kehiudpan bakteri. Bakteri yang dapat mencapai sumber air sebelum batas waktu hidup bakteri, dapat mempengaruhi kualitas air. Keadaan ini dapat menularkan diare melalui media air, atau media makanan yang terkontaminasi oleh
E.coli, Entamoeba hystolitica, Sygella, vibrio cholera, dan lain-lain agent penyebab penyakit.

Penelitian Bambang, S yang menyatatakan bahwa pengaruh terbesar terhadap keberadaan E.coli adalah jarak sumber air dari sumber pencemaran seperti kandang ternak, septik tank dan tempat sampah.

Penelitian yang juga dilakukan Joko Irianto (1996) bahwa sumber pencemar seperti Jamban keluarga, jarak antara jamban dengan septik tank mempunyai resiko paling tinggi terhadap rumah tangga yang tidak mempunyai fasilitas jamban keluarga. Kuatnya hubungan antara sumber pencemar jamban keluarga terhadap kualitas bakteriologis dimana tinja yang mengandung mikroorganisme/bibit penyakit dapat merupakan sumber terjadinya suatu penyakit yang dapat ditularkan melalui media air, baik langsung maupun tidak langsung melalui makanan dan minuman yang dikonsumsi oleh penjamu atau manusia.

Penelitian Yohanes, 2004 mengenai pengaruh jarak terhadap kualitas air sumur gali menyimpulkan, bahwa jarak mempengaruhi kualitas bakteriologis air. Semakin dekat jarak sumber pencemaran dengan sumber air minum, maka kemungkinan terkontaminasi semakin besar. Hal ini disebabkan cepatnya bakteri mencapai sumber air.

Konstruksi sumber air juga mempunyai peranan penting dalam kuliatas bakteriologis air. Pencemar dapat mencapai sumber air jika konstruksi sumber air tidak memenuhi syarat. Zat pencemar berfungsi sebagai media pembawa penyakit dan sebagai tempat berkembang biaknya bibit penyakit. Deborah dkk (2007) menjelaskan bahwa perbaikan konstruksi, perbaikan sanitasi serta akses air minum yang memenuhi syarat berdampak dalam penurunan prevalensi kejadian diare.

W.Robertson dkk (2007), menjelaskan lebih jauh bahwa, konstruksi sumber air bersih yang baik akan melindungi kontaminasi air dengan menghambat supply makanan bagi bakteri sehingga bakteri tidak berkembang. Dengan demikian dengan konstruksi yang baik berpengaruh terhadap keberadaan 
bakteri yang dapat menyebabkan diare. Penyakit-penyakit yang dapat ditimbulkan oleh air tercemar antara lain: cholera, typus abdominalis, Amuba disentry

Terdapatnya sejumlah penderita diare pada responden dengan kualitas bakteriogis yang memenuhi syarat disebabkan bahwa diare merupakan penyakit klasik yang tidak hanya dipengaruhi oleh air minum yang tidak memenuhi syarat, akan tetapi diare merupakan gejala penyakit yang multi kausa, misalnya tidak mencuci tangan dengan sabun setelah buang air besar dan sebelum makan, pengelolaan makanan yang tidak baik, dan berperilaku yang tidak bersih dan sehat, disamping itu beberapa faktor yang dapat terjadinya diare adalah makanan yang terkontaminasi bakteri Staphylococus, atau mengandung racun bakteri Clostridium serta status gizi, iklim, sosial ekonomi sehingga responden dengan pendapatan setiap harinya tidak menentu sangat susah untuk memenuhi kebutuhan hidup dan asupan gizi terbatas, sementara itu kejadian diare di Wawondula dalam penelitian ini tidak hanya dipengaruhi oleh kualitas bakteriologis air yang tidak memenuhi syarat saja tetapi banyak faktor yang dapat mempengaruhinya seperti makanan atau minuman yang kurang hygienis, perilaku hidup yang tidak bersih dan sehat, misalnya makan dengan tidak memperhatikan kebersihan tangan, dan alat makan/minum seperti piring, sendok, gelas. Ini semua dapat menyebabkan kejadian diare secara tidak langsung apabila agen penyakit penyebab utama telah mencemari alat makanan tersebut.

Faktor lain yang dapat menyebabkan diare adalah stres atau alergi terhadap makanan/minuman tertentu. Perkembangan penderita diare jika dilihat dari waktu maka terjadinya diare biasanya pada musim buah-buahan yang menjadi transmitor adalah lalat yang mencemari makanan manusia, demikian juga pada musim kemarau dapat meningkatkan frekwensi kejadian diare, karena pada saat air bersih sulit didapatkan maka masyarakat akan memanfaatkan air yang apa adanya, yang tidak memenuhi syarat kesehatan, sementara pada musim hujan maka, masyarakat akan cenderung menggunakan sumber air yang tidak terkontrol.

\section{Analisis Hubungan Tindakan Pengolahan dengan Kejadian Diare}

Bakteri coliform merupakan indikator yang menunjukkan adanya organisme pathogen dalam air. Ditemukannya bakteri coliform dalam air berarti kemungkinan adanya bakteri pathogen yang berasal dari tinja. Bila bakteri pathogen masuk ke dalam air, maka bakteri tersebut akan hidup selama beberapa hari. Apabila air tersebut diminum maka bakteri yang masih hidup akan masuk ke usus dan berkembang biak sehingga menimbulkan penyakit.

Adapun upaya yang dilakukan untuk membunuh kuman/ bakteri pathogen adalah desinfeksi. Proses desinfeksi dapat dilakukan dengan cara kimia, fisis, mekanis dan radiasi. Secara umum tindakan pengolahan, yang paling sering dilakukan adalah dimasak sebelum dikonsumsi.

Hasil penelitian menunjukan menunjukan bahwa responden yang tindakan pengolahan memenuhi syarat dan menderita diare sebanyak 11 responden (10.4\%), dan responden dengan tindakan pengolahan yang tidak memenuhi syarat dan menderita diare sebanyak 89 responden (94.7\%). Hal ini menunjukan bahwa persentase penderita diare pada responden dengan tindakan pengolahan yang tidak memenuhi syarat lebih tinggi dibanding pada responden yang melakukan tindakan pendolahan memenuhi syarat. Secara terdapat hubungan yang signifikan dengan nilai $p=0.000 \quad(p<0,05)$, artinya terdapat hubungan yang bermakna antara tindakan pengolahan dengan kejadian diare di Wawondula..

Munjed dkk, menjelaskan bahwa menggunakan sumber air sebagai air minum tanpa tindakan pengolahan atau treatment merupakan faktor yang sangat mempengaruhi terjadinya kejadian diare.

Kebiasaan di masyarakat sampai saat ini masih ada yang menkonsumsi air minum tanpa 
dimasak sampai mendidih. Mereka mengambil air kemudian menampung di tempat khusus dan dijadikan sebagai air minum. Kenyataan ini bisa membawa kepada terjadinya penyakit diare bila suatu waktu tubuh tidak kuat lagi untuk mempertahankan kondisi prima. Mengkosumsi air tanpa dimasak juga belum tentu menyebabkan diare.

Banyak masyarakat yang mengkonsumsi air tanpa dimasak, akan tetapi tidak menderita diare. Hal ini karena terbentuknya antibodi dalam tubuh. Waktu pertama mengkonsumsi air minum tanpa dimasak mungkin tidak sakit atau sakit, tapi ringan.. Ketika tiap hari mengkonsumsi air tanpa dimasak, maka antibodi yang terbentuk akan semakin kuat.

Responden di Wawondula melakukan tindakan pengolahan dengan cara dimasak. Setelah itu disimpan dalam wadah tertutup, sehingga kemungkinan terkontaminasi dengan bakteri sangat kecil. Dalam hal tindakan pengolahan dipengaruhi juga pendidikan responden. Pendidikan yang dimiliki oleh ibu dalam pengolahan air merupakan faktor yang penting untuk mencegah penyakit diare. Semakin tinggi tingkat pendidikan maka peranan yang diberikannya sangat besar dalam hal pencegahan penyakit diare.

\section{Analisis Hubungan Perilaku Hygiene dengan Kejadian Diare \\ Perilaku Hygiene adalah} usaha kesehatan perorangan yang mencakup tentang pemeliharaan kesehatan, dengan usaha aturanaturan hidup dan prinsip-prinsip untuk melindungi kesehatan secara pribadi.

Hasil penelitian menunjukan bahwa responden dengan perilaku hygiene yang memenuhi syarat dan menderita diare sebanyak 21 responden (18.4\%), dan responden dengan prilaku hygiene yang tidak memenuhi syarat dan menderita diare sebanyak 79 responden $(79.0 \%)$. Hal ini menunjukan bahwa persentase penderita diare pada responden dengan perilaku hygiene yang tidak memenuhi syarat lebih tinggi dibanding pada responden dengan perilaku hygiene memenuhi syarat. Secara statistik terdapat hubungan yang signifikan dengan nilai $p=0.000$ $(p<0,05)$, artinya terdapat hubungan yang bermakna antara perilaku hygiene dengan kejadian diare di Wawondula

Hygiene dan kebersihan umum yang kurang baik merupakan faktor mempermudah penularan penyakit diare di lingkungan keluarga maupun di masyarakat seperti yang dikemukakan oleh Abraham $\mathrm{S}$. Benenson bahwa Hygiene merupakan tindakan-tindakan pencegahan terutama yang menyangkut tanggung jawab perorangan untuk memelihara kesehatan dan mencegah atau membatasi penyebaran penyakit infeksi, utamanya penyakit-penyakit menular langsung.

Tindakan-tindakan hygienes meliputi: Mencuci tangan dengan sabun dan air sesudah buang air dan juga setiap akan mengolah makanan atau minuman, menjauhkan tangan dan benda-benda yang telah digunakan atau yang tidak bersih untuk membersihkan dari mulut, hidung, mata, telinga dan luka, menghindarkan penggunaan alat-alat makan, gelas, handuk, sapu tangan, sisir, sikat rambut dan pipa rokok secara bersama-sama yang tidak bersih. Cuci tangan bersih-bersih sesudah menangani atau memegang benda-benda kepunyaan penderita diare.

Tindakan hygienes yang berhubungan dengan kejadian diare dalam hal ini dibatasi pada Menghindarkan responden terhadap hal-hal yang dapat mengakibatkan diare dan terpaparnya orang lain dari pengaruh orang atau hal yang dapat mengakibtakan diare.

\section{E. KESIMPULAN DAN SARAN}

1. Persentase kualitas bakteriologis pada jarak dengan sumber pencemaran yang tidak memenuhi syarat lebih tinggi dibanding pada responden dengan jarak sumber pencemar yang memenuhi syarat.).

2. Persentase kualitas bakteriologis pada konstruksi yang tidak memenuhi syarat lebih tinggi dibanding pada responden dengan konstruksi yang memenuhi syarat . 
3. Persentase penderita diare pada kualitas bakteriologis yang tidak memenuhi syarat lebih tinggi dibanding pada responden dengan kualitas bakteriologis memenuhi syarat.

4. Persentase penderita diare pada responden dengan tindakan pengolahan yang tidak memenuhi syarat lebih tinggi dibanding pada responden yang melakukan tindakan pendolahan memenuhi syarat.

5. Persentase penderita diare pada responden dengan prilaku hygiene yang tidak memenuhi syarat lebih tinggi dibanding pada responden dengan perilaku hygiene memenuhi syarat.

6. Variabel yang paling berpengaruh terhadap kejadian diare adalah tindakan pengolahan responden terhadap air minum

\section{Saran}

1. Disarankan kepada Pihak PT.Vale Sorowako agar menyediakan sumber air minum yang memenuhi syarat di wawondula sebagai wilayah pemberdayaan.

2. Kepada Masyarakat diharapkan agar, melakukan tindakan pencegahan penyakit diare dengan melakukan pemanasan sampai mendidih sebelum mengkongsumsi air minum serta senantiasa berprilaku hygiene dengan mencuci tangan dengan sabun setelah buang air besar dan sebelum makan dan minum.

2. Diharapkan kepada Petugas puskesmas dalam melakukan pencegahan terhadap meluasnya kejadian diare untuk lebih mendekatkan diri kepada masyarakat dalam rangka pemberian informasi melalui penyuluhan kesehatan secara terus menerus tentang pentingnya air minum yang memenuhi syarat

\section{DAFTAR PUSTAKA}

Departemen Kesehatan RI. 1990. Pengelolaan Tinja dan Air Limbah, Jakarta: Diknakes RI

Petunjuk Pemakaian Alat Paket A Sistem Tabung
Ganda Untuk Pemeriksaan Bakteriologis

Surat Keputusan Menteri Kesehatan, Kepmenkes RI, 1216/SK/XI/2001 tentang pedoman penanggulangan Penyakit Diare 2004. Menkes resmikan Proyek Air Bersih dan Sanitasi Untuk Masyarakat Berpenghasilan Rendah.

(http://www.depkes.go.id. di akses 8 Agustus 2005)

Deborah, dkk.2007 Health Impact of Water and Sanitation Infrastructure Reconstruction Programmes in Eight Central American Communities Affected by Hurricane Mith, Journal of Water and Health, Vol.05 No 1 pp 51-65 doi:10.2166/wh.2007.047

Daud, Anwar. 2001. Aspek Kesehatan Penyediaan Air Bersih, Makassar: Jurusan Kesehatan Lingkungan, FKM Unhas

Djaffar,M.Hasyim, 2000. Penyediaan Air Bersih (PAB), Makassar: Jurusan Kesehatan Lingkungan FKM-UNHAS.

Herlambang. 2007. Masalah Pencemaran Air, Sumber dan Penanggulangannya, Jakarta :BPPT, ,

Jalaluddin. 2004. Analisis Pola Penyakit Berbasis Lingkungan di Daerah Pesisir, Daratan, dan Pegunungan di kabupaten Wajo,. Makassar; Pascasarjana Universitas Hasanuddin. Tesis tidak diterbitkan

Marzuki H. 2004.Peranan Air Bersih atas Terjadinya Penyakit Diare dalam Wilayah Pelabuhan Kendari yang Menggunakan Sumur Gali dan Sumur Pompa, Kendari.

Munjed Al-Sharif dkk. 2007. Assessing Water and Health Linkages In irbid, Jordan, Assessment and Valuation Development Polices, Amman.

Notoatmodjo, Soekidjo. 2002. Metodologi Penelitian Kesehatan, Jakarta : Rineka Cipta 
2003. ILmu Kesehatan Masyarakat, Jakarta: Rineka Cipta,

Pikiran Rakyat. 16 Agustus 2003. Diare, Tampak remeh, Tapi Bisa Mematikan http://www.pikiran-rakyat.com diakses 8 Agustus 2005)

Pajung, L. 2008. Laporan Kegiatan Rumah Sakit PT.Inco, Coops Unhas - PT.Inco, Soroako, 2008

Rahmadi R, 2005. Di Bali, Diare Memakan Korban Jiwa (http://www.tempo.co.id. Diakses 8 Agustus 2005)

Republik Indonesia. 1990. Peraturan Menteri Kesehatan RI, Nomor :416/Menkes/Per/IX/1990 tentang Syarat-syarat dan Pengawasan Kualitas Air. 2010. Peraturan Menteri Kesehatan $\mathrm{RI}$, 492/Menkes/PER/IV/2010 tentang Syarat-syarat Kualitas Air Minum

Rihadi S. 2005. Pencegahan dan Pemberantaan Penyakit Berbasis Lingkungan Melalui JPS-BK, Subdin Bina Penyehatan Lingkungan, Dinas Kesehatan Prov. Jawa Timur (http://www.tempo.co.id/medik a. diakses 8 Agustus 2005 )

Sam,A. 2004. Analisis Kualitas Air Sumur Gali dan Jamban
Keluarga Terhadap Kejadian Diare di Kecamatan Barebbo Kabupaten Bone. Makassar; Pascasarjana Universitas Hasanuddin. Tesis tidak diterbitkan.

Sanropie, Djasio dkk.1994. Pedoman Bidang Studi Penyediaan Air Bersih APK-TS. Jakarta: Pusat Pendidikan Tenaga Kesehatan, Depkes RI.

Seweng. Arifin. 2010. Statistik Terapan dalam Bidang Kesehatan, Bagian Biostatistik/KKB, Makassar: Fakultas Kesehatan Masyarakat, Unhas.

Slamet, Juli Sumirat. 2000. Kesehatan Lingkungan, Jakarta, Gajah Mada University Press,

Suharyono. 1991. Diare Akut, Jakarta: Rineka Cipta,

Tjitra,E. 2006. Faktor Resiko Yang mempengaruhi Keskitan Diare pada Balita http://digilib.litbang.depkes.go.id, diakses 19 Mei 2006).

W.Robertson. 2007. Monitoring The Quality Of drinking Water During Storage And Distribution, New York: WHO.

Yohanes. 2004. Pengaruh Jarak Terhadap Kualitas Air Sumur Gali Penduduk di Sekitar Pinggir Sungai Sa'dan Kabupaten Tana Toraja, Jurnal ilmiah Kesehatan Lingkungan Tahun 1 No 2 Hal. $118-133$. 